\title{
Performance Analysis of Positive Lift LUO Converter
}

\author{
Ms. Madhuri Zambre \\ Research Scholar, P.V.G College of Engineering Pune India \\ madhurizambre01@gmail.com
}

\begin{tabular}{|c|c|}
\hline Article History & Abstract \\
\hline $\begin{array}{c}\text { Article Submission } \\
18 \text { October } 2011 \\
\text { Revised Submission } \\
22 \text { January } 2012 \\
\text { Article Accepted } \\
2 \text { February } 2012 \\
\text { Article Published } \\
31^{\text {st }} \text { March } 2012\end{array}$ & $\begin{array}{l}\text { The quick depletion of remnant fuels, environmental pollution has become more solemn } \\
\text { matter. Recently a good deal effort made to find renewable energies and solar energy is } \\
\text { the ideal solution. In photovoltaic arrays, cells are arranged in series to obtain the } \\
\text { required voltage. The output characteristic feature of photovoltaic array show a } \\
\text { discrepancy radically by way of solar irradiation, temperature and presents MPP under } \\
\text { various atmospheric nominal conditions. Based on Perturbation and Observation } \\
\text { method, MPP is tracked for PV. The DC-DC converter is used to improve the output } \\
\text { voltage and are widely used in solar energy conversion systems.. Here ultra-lift LUO } \\
\text { converters are normally used to convert low input voltage in to high output voltage } \\
\text { (same principle of Boost converter). But these converters are not stable in voltage lift } \\
\text { and less reliability. By using Voltage lift method, voltage transfer gain higher than } \\
\text { other classical converters is obtained. } \\
\text { Keywords: LUO Converter, MPP, Renewable Energy }\end{array}$ \\
\hline
\end{tabular}

\section{Introduction}

Energy crisis pertaining in the world lead us for search of alternative energy. The solar energy find greater importance as it is profuse, free \& inexpensive, pollution less and widely distributed all over the world. The demand for solar energy is growing because of reduced price, improvement in efficiency of the solar cells and its manufacturing process. The operating condition of photovoltaic cells are greatly influenced by solar radiation, temperature of the solar cell and load cell values. The novelty of the PV cell is that it has a unique point at which it gives out maximum power output. There is a great necessity to develop a simulation model for photovoltaic cells to understand the efficiency of the converters and PV arrays. This proposed paper analyses the principle behavior of Photovoltaic cell power and presents a mathematical model. All the simulations are performed using MATLAB environment.

Current equation for PV panel is given

$$
I=I_{P V_{\text {seil }}}-I_{0, \text { setll }}\left(e^{\frac{q v}{a k t}}-1\right)
$$

$\mathrm{I}_{\mathrm{PV}}$, cell is the Current generated by the solar light, q represents charge of the electron, $\mathrm{k}$-Boltzmann constant, $\mathrm{t}$-the existing temperature, a -diode constant. 
Equation to calculate PV current

$$
I_{n}=\left(I_{p i n}+K_{1} \Delta T\right) \frac{G}{G_{n}}
$$

$\mathrm{n}$ is the number of solar cells arranged in series

$\Delta \mathrm{T}$ is change in temperature

$\mathrm{G}$ is irradiance

$\mathrm{Gn}$ is nominal irradiance

Thermal voltage equation for the solar panel is given below

$$
V,=\frac{N, k T}{q}
$$

Equation for change in temperature is given below

$$
\Delta_{T}=T-T_{n}
$$

\section{Simulation model of PV Array}

First the photovoltaic cells are connected series to make it in an array fashion, the array is represented in mathematical form as a single cell through multipliers integrated for that reason. Hence, the experimental model of the PV array is dependent on the amount of series/parallel manacles in array. The simulation models of photovoltaic array depending upon single and double index model are recognized respectively. Single and double index model linked together to form function module in MATLAB simulation environment.
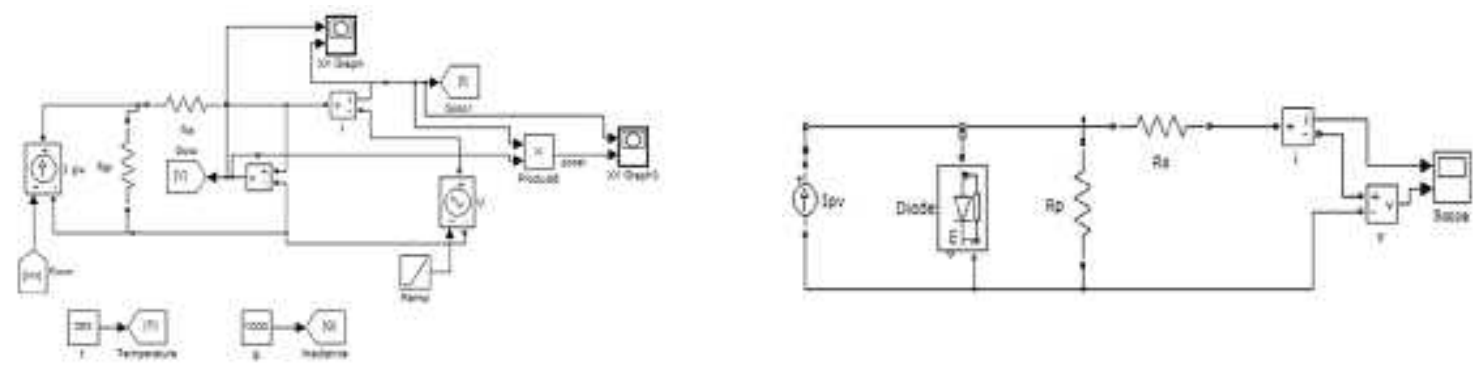

Fig.1: Simulink model of photovoltaic panel 

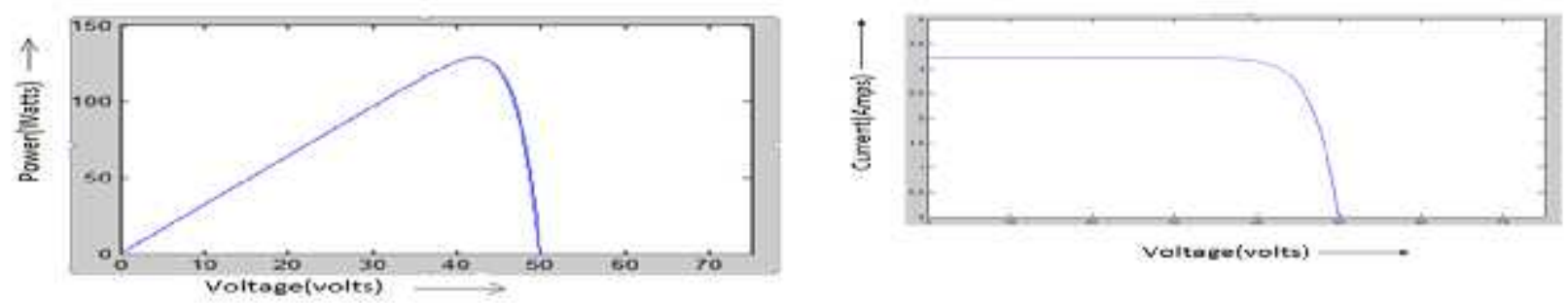

Fig.2: The power Vs. Voltage graph for photovoltaic panel

\section{DC-DC conversion}

In this part DC-DC conversion is did by the LUO converter. This LUO converter has positive lift LUO converter and negative lift LUO converter this works on voltage lift technique. Voltage lift technique is generally applied in industrial application. In this it works same as like the boost converter where the output voltage increases triple time of the input voltage. The circuit representation for LUO converter is given in MATLAB simulation as shown in figure 3 .
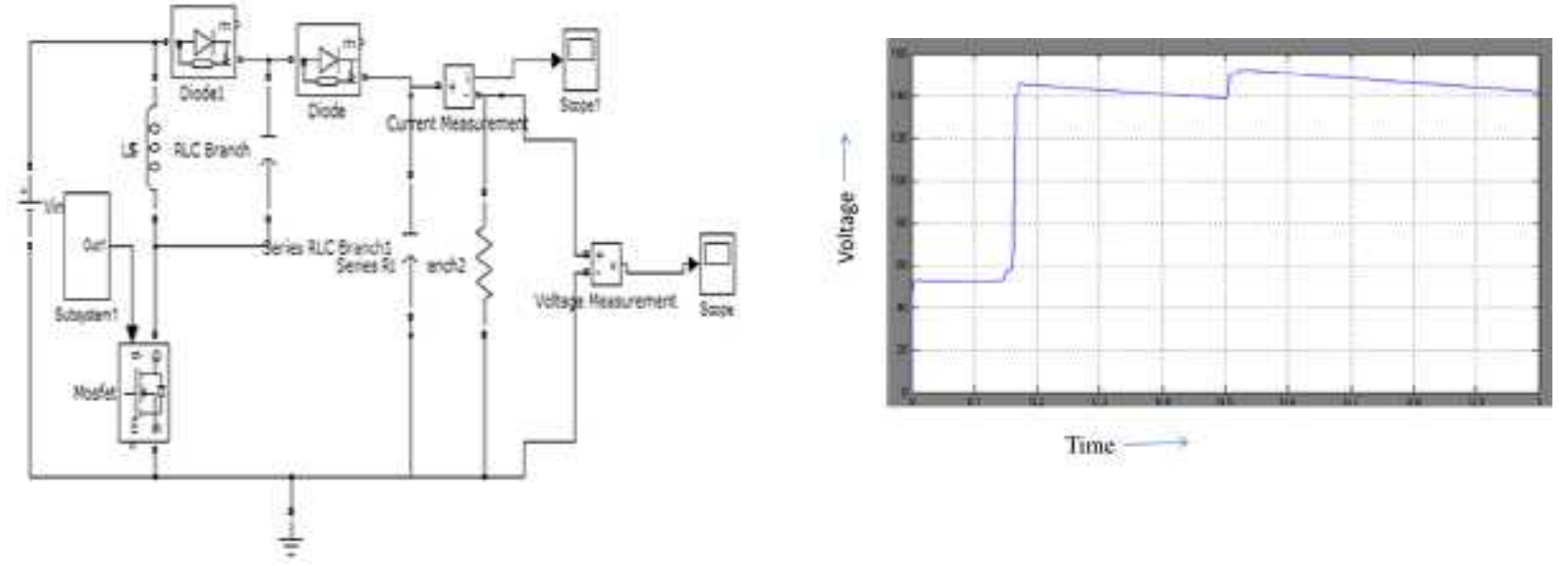

Fig.3: Simulink model and graph of DC-DC conversion

For this converter the calculated value is given in the table below

Table 1: Parameters and Values

\begin{tabular}{|c|c|}
\hline Parameters name & Value \\
\hline Input voltage & $50 \mathrm{~V}$ \\
\hline Output voltage & $150 \mathrm{~V}$ \\
\hline $\mathrm{L} 1$ & $1 \boldsymbol{\mu H}$ \\
\hline $\mathrm{C} 1, \mathrm{C} 2$ & $50 \mathrm{mF}$ \\
\hline $\mathrm{R}$ & $50 \Omega$ \\
\hline
\end{tabular}

ISSN: 2250-0839 
In this graph shown in fig 3, the shoot over period respectively from $140 \mathrm{~V}-152 \mathrm{~V}$ respectively. Here it is absorbed that the obtained output from the PV panel is not a regulated DC voltage there by combining it with the converter it is possible to regulate and boost the output voltage obtained. The output obtained from this circuit is fed as the gate pulse to the converter circuit. Pulse input given to the converter is given below

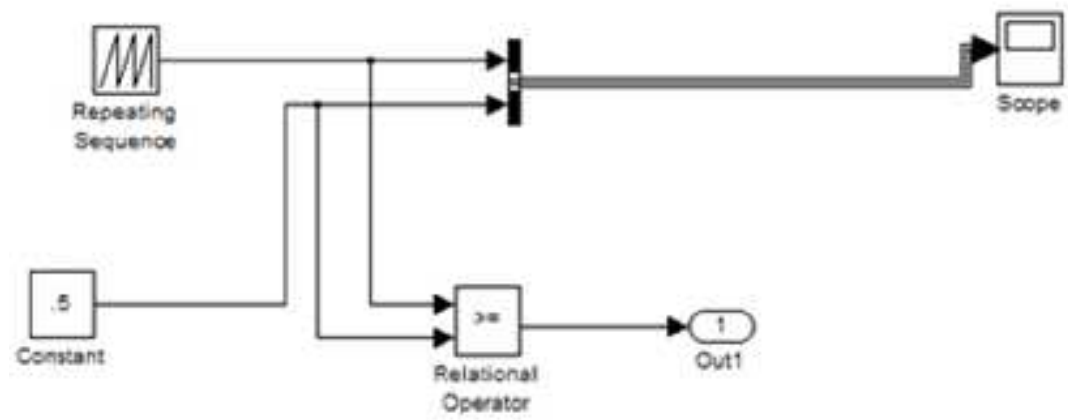

Fig.4: Pulse input to DC-DC converter

\section{Inverter circuit to convert DC-AC}

After this process this circuit is combined with the inverter to convert the obtained DC voltage to the AC voltage respectively in order to convert H-Bridge inverter is used. With this the individual circuit analysis is completed. In the next set after combining converter and inverter the output is obtained in such a manner.
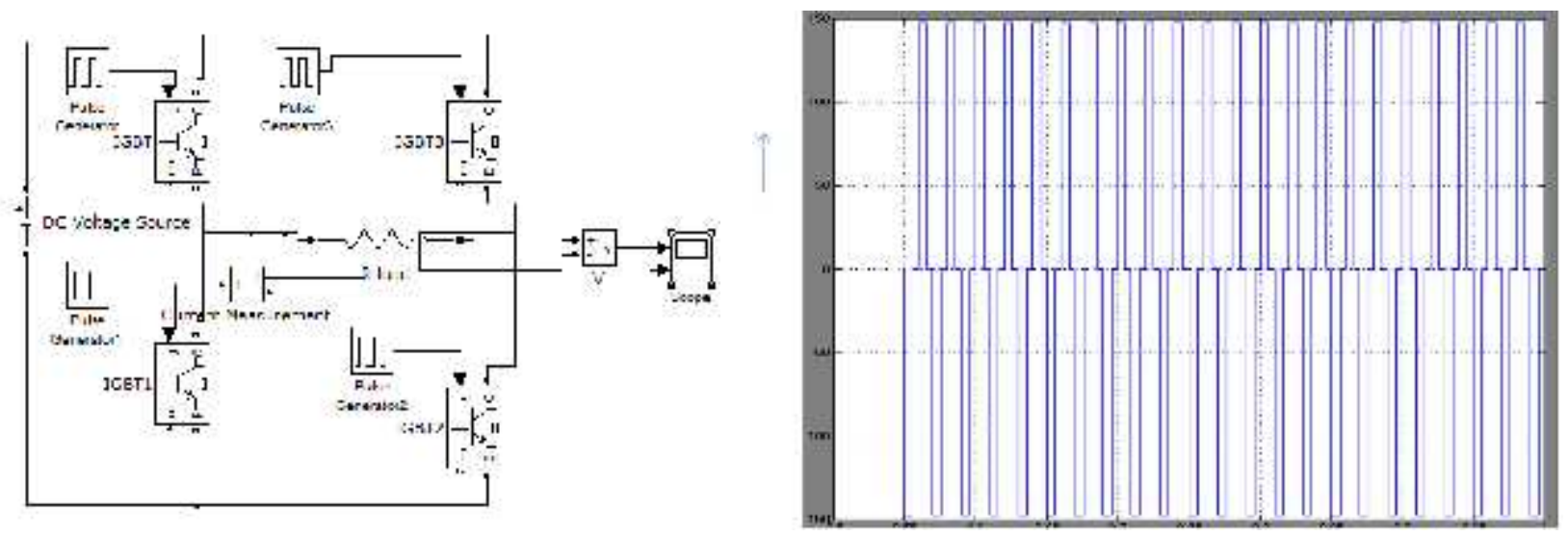

Fig.5: Simulink model and graph of DC-AC conversion

After combining the converter and inverter obtained result is given below there it will have losses in the circuit losses ranges from (30-40) volts respectively. 

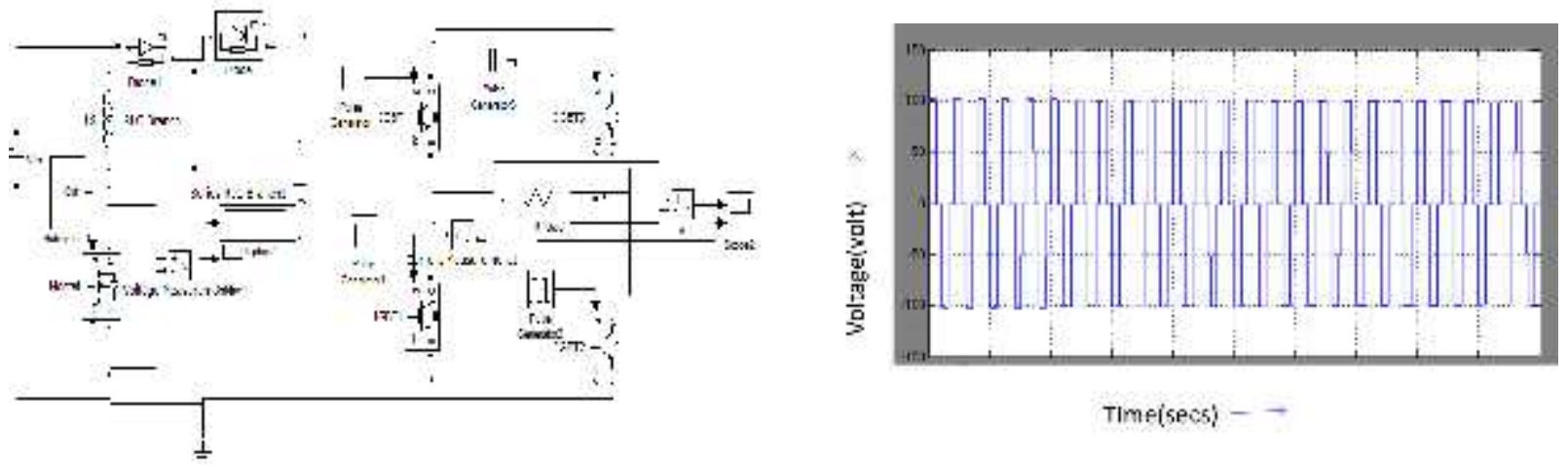

Fig. 5: Simulink model and graph of DC-AC conversion

\section{MPPT (Maximum power point tracking)}

MPPT utilizes a well-established control circuit to look for maximum power point and enhancing the converter to extract highest maximum power from the photovoltaic panel. This tracking leads to the increase or decrease in power in the either direction. Hence, the peak power tracker endlessly seek the peak power condition.

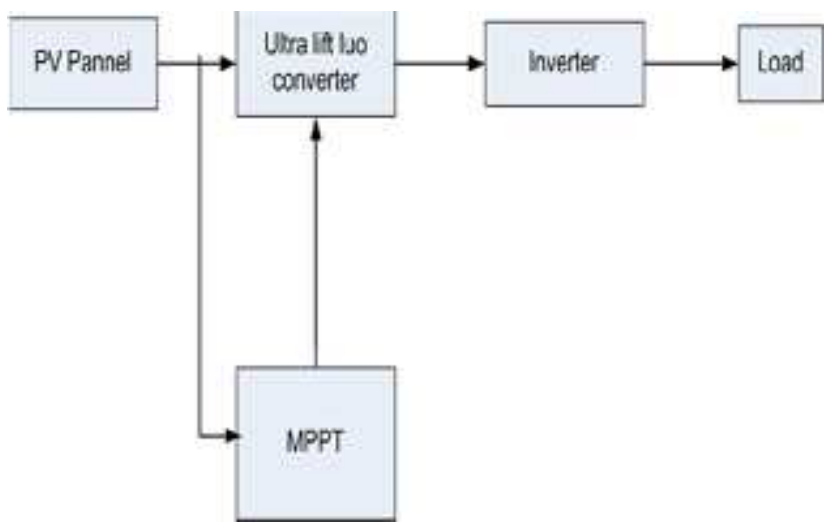

Fig. 6: Block of MPPT implementation

The simulated diagram of the P\&O method is given below in the figure 7 . After combining all these the expected result for this circuit is to improve the output voltage for $100 \mathrm{~V}$. 


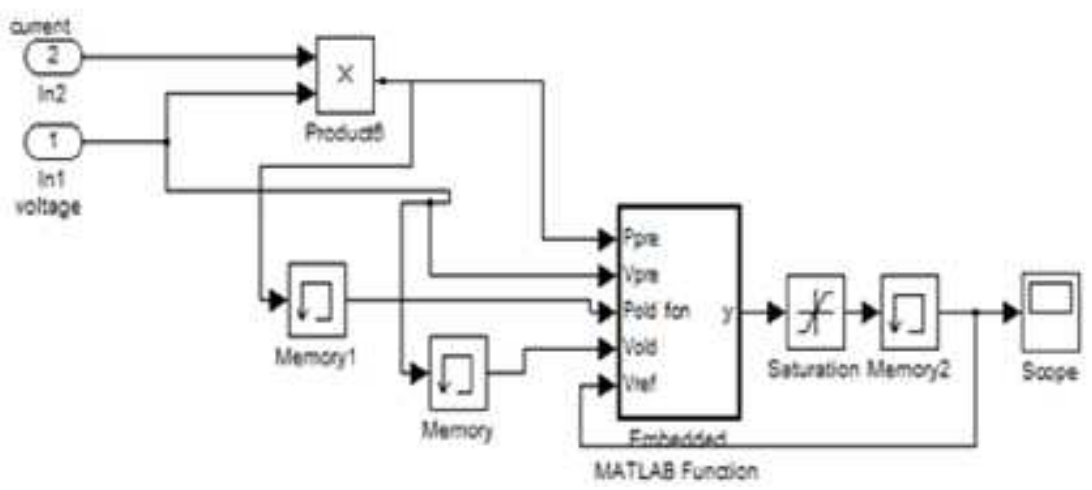

Fig.7: Simulink model of $P \& O$ Method

\section{Conclusion}

There are various controlling algorithm which are used for tracking MPP here $\mathrm{P} \& \mathrm{O}$ technique is implemented. $\mathrm{P} \& \mathrm{O}$ is abbreviated as Perturbation and observation. The proposed method has a simple feedback construction and a few essential parameters. The operation periodically increases or decreases the arrays terminal voltage. A comparison is made between the Photovoltaic output powers with that of the prior obtained value power value. The main advantage with this method is its simplicity and its easy implementation.

\section{References}

[1] Petreuş, D., Fărcaş, C., \& Ciocan, I. (2008). Modelling and simulation of photovoltaic cells. Acta Technica Napocensis-Electronics and Telecommunications, 49(1), 42-47.

[2] Villalva, M. G., Gazoli, J. R., \& Ruppert Filho, E. (2009, September). Modeling and circuit-based simulation of photovoltaic arrays. In 2009 Brazilian Power Electronics Conference (pp. 1244-1254). IEEE.

[3] LUO, F. L., \& Ye, H. (2005). Ultra-lift LUO-converter. IEE Proceedings-Electric Power Applications, 152(1), 27-32.

[4] S Gomathy, S. S. T. S., Saravanan, S., \& Thangavel, S. (2012). Design and implementation of maximum power point tracking (MPPT) algorithm for a standalone PV system. International Journal of Scientific \& Engineering Research, 3(3), 1-7.

[5] Das, B., Jamatia, A., Chakraborti, A., Kasari, P. R., \& Bhowmik, M. (2012). New perturb and observe MPPT algorithm and its validation using data from PV module. International Journal of Advances in Engineering \& Technology,4(1),579.

[6] A. K. Abdelsalam, A. M. Massoud, S. Ahmed and P. N. Enjeti, "High-Performance Adaptive Perturb and Observe MPPT Technique for Photovoltaic-Based Microgrids," in IEEE Transactions on Power Electronics, vol. 26, no. 4, pp. 1010-1021, April 2011.

[7] M. A. G. de Brito, L. P. Sampaio, G. Luigi, G. A. e Melo and C. A. Canesin, "Comparative analysis of MPPT techniques for PV applications," 2011 International Conference on Clean Electrical Power (ICCEP), Ischia, 2011, pp. 99-104.

[8] A. Durgadevi, S. Arulselvi and S. P. Natarajan, "Study and implementation of Maximum Power Point Tracking (MPPT) algorithm for Photovoltaic systems," 2011 1st International Conference on Electrical Energy Systems, Newport Beach, CA, 2011, pp. 240-245. 